\title{
Overview of recent cases before the european court of human rights (December 2017 - August 2018)
}

European Journal of Social Security 2018, Vol. 20(3) 284-293 (C) The Author(s) 2018 Article reuse guidelines: sagepub.com/journals-permissions DOI: $10.1177 / 13882627 / 8802132$ journals.sagepub.com/home/ejs

(S)SAGE

\section{Marcin Wujczyk}

Department of Labour Law and Social Policy, Jagiellonian University, Kraków, Poland

\section{Prohibition of discrimination with respect to the right to pension, regardless of citizenship (Ribać v. Slovenia)'}

This report refers to the judgment of the European Court of Human Rights of 5 December 2017. The applicant, Aranđel Ribać, stated in his complaint that the refusal to grant him an old-age pension because he did not hold Slovenian citizenship constituted discrimination on the grounds of nationality, contrary to Article 14 of the Convention ${ }^{2}$ taken in conjunction with Article 1 of Protocol No. $1 .^{3}$

\section{Factual state}

The Socialist Federal Republic of Yugoslavia (the SFRY) was a federal State composed of six republics: Bosnia and Herzegovina, Croatia, Serbia, Slovenia, Montenegro, and Macedonia. Nationals of the SFRY had dual citizenship for internal purposes, that is to say they were citizens of both the SFRY and one of the six republics. They had freedom of movement within the federal

1. Application no. 57101/10).

2. Art. 14 of the Convention: 'The enjoyment of the rights and freedoms set forth in [the] Convention shall be secured without discrimination on any ground such as sex, race, colour, language, religion, political or other opinion, national or social origin, association with a national minority, property, birth or other status.'

3. Article 1 of Protocol No. 1: 'Every natural or legal person is entitled to the peaceful enjoyment of his possessions. No one shall be deprived of his possessions except in the public interest and subject to the conditions provided for by law and by the general principles of international law. The preceding provisions shall not, however, in any way impair the right of a State to enforce such laws as it deems necessary to control the use of property in accordance with the general interest or to secure the payment of taxes or other contributions or penalties.'

\section{Corresponding author:}

Marcin Wujczyk, Department of Labour Law and Social Policy, Jagiellonian University, Gołębia 24, 31-007, Kraków, Poland. E-mail: marcin.wujczyk@uj.edu.pl 
State and could register as permanent residents wherever they settled on its territory. ${ }^{4}$ The SFRY had two pension systems - military and civil. The pension rights of military personnel were regulated by and secured through the federal authorities. In particular, members of the Yugoslav People's Army (hereinafter the YPA), the armed forces of the SFRY, paid their contributions to and received their pensions from a special military pension fund based in Belgrade (hereinafter the YPA Fund). The YPA Fund paid pensions to military pensioners irrespective of where they undertook military service or lived once retired. This was the only pension fund existing at federal level. In parallel, each republic had in place its own pension legislation and a public pension fund set up for the payment of civil pensions.

After Slovenia declared independence, it introduced a comprehensive regulatory framework for the pension rights of former YPA military personnel, in most cases allowing for pensions to be paid only to Slovenian nationals. ${ }^{5}$

The applicant was a citizen of the Republic of Serbia in the SFRY. Following its dissolution, he retained citizenship of the then Federal Republic of Yugoslavia. He had been residing in Slovenia since 1964 and had had permanent resident status since 1981. However, he became a citizen of Slovenia only on 1 April 2003.

On 13 November 1991 the YPA Fund found the applicant to be entitled to an old-age pension under the SFRY military rules as from 1 October 1991 with more than 41 pensionable years together with a with bonus (benificirana doba) in the YPA. The applicant maintained that he had only received his pension from the YPA Fund twice (in November 1991 and January 1992), when he had personally gone to Belgrade to collect it. ${ }^{6}$ In the period from November 1998 to April 2003 the applicant had been denied an old-age pension on the grounds that he did not hold Slovenian citizenship, which was one of the requirements under binding legal regulations.

\section{Prohibition of discrimination regulated in Article 14 of the convention as a non- independent basis for protection}

The Court reiterated that Article 14 of the Convention complements the other substantive provisions of the Convention and its Protocols. It has no independent existence, since it has effect solely in relation to 'the enjoyment of the rights and freedoms' safeguarded by those provisions. The application of Article 14 does not necessarily presuppose the violation of one of the substantive rights guaranteed by the Convention. It is necessary but it is also sufficient for the facts of the case to fall 'within the ambit' of one or more of the Convention Articles. ${ }^{7}$ The Court emphasised that the prohibition of discrimination in Article 14 thus extends beyond the enjoyment of the rights and freedoms which the Convention and Protocols require each State to guarantee. It applies also to those additional rights, falling within the general scope of any Convention Article, which the State has voluntarily decided to provide. ${ }^{8}$

4. Ibid: [6].

5. Ibid: [9].

6. Ibid: [13]

7. See, among many other authorities, Andrejeva v. Latvia [GC], no. 55707/00, § 74, ECHR 2009; and Lupeni Greek Catholic Parish and Others v. Romania [GC], no. 76943/11, § 162, ECHR 2016 (extracts).

8. See Stec and Others v. the United Kingdom (dec.) [GC], nos. 65731/01 and 65900/01, § 40, ECHR 2005 X; and Khamtokhu and Aksenchik v. Russia [GC], nos. 60367/08 and 961/11, § 58, ECHR 2017. 
According to the Court's established case law, the principles which apply generally in cases concerning Article 1 of Protocol No. 1 are equally relevant when it comes to welfare benefits. ${ }^{9}$ However, this Article does not guarantee the right to acquire property, ${ }^{10}$ nor does it guarantee, as such, any right to a pension of a particular amount. ${ }^{11}$ Furthermore, it places no restriction on the Contracting State's freedom to decide whether or not to have in place any form of social security scheme, or to choose the type or amount of benefits to provide under any such scheme. If, however, a Contracting State has in force legislation providing for the payment as of right of a welfare benefit - whether conditional on the prior payment of contributions or not - that legislation must be regarded as generating a propriety interest falling within the ambit of Article 1 of Protocol No. 1 for persons satisfying its requirements. ${ }^{12}$

Based on available information, the Court decided that the applicant would have had a right, enforceable under domestic law, unless the discriminating criterion comprised the requirement to have Slovenian citizenship had been applied. ${ }^{13}$ As a result, the Court concluded that the applicant's pecuniary interest fell within the scope of Article 1 of Protocol No. 1 and the right to the peaceful enjoyment of possessions which it safeguards. ${ }^{14}$

\section{Limitations of the prohibition of discrimination with respect to access to social security benefits}

The Court reiterated that, although Article 1 of Protocol No. 1 does not comprise the right to receive a social security payment of any kind, if a State does decide to create a benefit scheme, it must do so in a manner which is compatible with Article 14 of the Convention. ${ }^{15}$ The Court stated that, in the enjoyment of the rights and freedoms guaranteed by the Convention, Article 14 affords protection against different treatment, without an objective and reasonable justification, of persons in relevantly similar situations. ${ }^{16}$ For the purposes of Article 14, a difference of treatment is discriminatory if it has no objective and reasonable justification; in other words, if it does not pursue a legitimate aim or if there is not a reasonable relationship of proportionality between the means employed and the aim sought to be realised. ${ }^{17}$

In the judgment analysed below, the Court pointed out that the contracting States enjoy a certain margin of appreciation in assessing whether and to what extent differences in otherwise similar situations justify a difference in treatment. ${ }^{18}$ The scope of this margin will vary according to the circumstances, the subject matter and the background. A wide margin is usually granted to a State under the Convention when it comes to general measures of economic or social strategy. ${ }^{19}$ The Court emphasised that, because of their direct knowledge of their society and its needs, the national authorities are in principle better placed than an international judge to appreciate what is in the

\footnotetext{
9. See Andrejeva, cited above, §77, and more recently, Ruszkowska v. Poland, no. 6717/08, § 48, 1 July 2014

10. See Kopecky'v. Slovakia [GC], no. 44912/98, § 35, ECHR 2004 IX.

11. See, for example, Béláné Nagy v. Hungary [GC], no. 53080/13, § 84, ECHR 2016.

12. Ibid: [40].

13. Ibid: [42] - [44].

14. Ibid: [45].

15. Ibid: [51].

16. Ibid: [52].

17. See Carson and Others v. the United Kingdom [GC], no. 42184/05, § 61, ECHR 2010.

18. See Izzettin Dogan and Others v. Turkey [GC], no. 62649/10, § 156, ECHR 2016.

19. See British Gurkha Welfare Society and Others v. the United Kingdom, no. 44818/11, § 62, 15 September 2016.
} 
public interest on social or economic grounds, and it generally accepts the legislature's policy choice unless it is 'manifestly without reasonable foundation' ${ }^{20}$ However, as a general rule, very weighty reasons that could be put before the Court, as mentioned in ECHR decisions, could regard a difference in treatment based exclusively on the grounds of nationality as compatible with the Convention. $^{21}$

As far as the burden of proof in respect of Article 14 of the Convention is concerned, the Court has established that once the applicant has shown a difference in treatment it is for the government to show that it was justified. ${ }^{22}$

\section{Judgment}

The Court decided that in this case there was a violation of Article 14 of the Convention taken in conjunction with Article 1 of Protocol No. 1.

The main basis for this judgment was the determination that the applicant, when his pension rights were determined in 1998, was in a relevantly similar situation to retired YPA military personnel with Slovenian citizenship. This was supported by the following circumstances:

a) The applicant had lived in Slovenia since 1964, established a family life there and had been registered as a permanent resident there since 1981.

b) The applicant, like other YPA military personnel, paid pension contributions to a federal pension fund (the YPA Fund).

c) The applicant was entitled to a pension under the conditions set out in the SFRY military rules, which applied to all beneficiaries regardless of their nationality.

d) In 1998 the applicant fulfilled all other statutory conditions entitling him to the pension except holding Slovenian citizenship. ${ }^{23}$

e) There are not enough grounds to claim that the applicant, as a foreign national, could not be compared to Slovenian nationals because he, unlike them, had been entitled to pension rights in Serbia as well as under the YPA Fund. ${ }^{24}$

The Court did not find any grounds for stating that the difference in treatment was objective and reasonably justified. Although the Court stated that the difference in the treatment complained of pursued at least one legitimate aim that was broadly compatible with the general objectives of the Convention, namely the protection and organisation of the country's economic and social system, ${ }^{25}$ it did not find any arguments that would allow it to consider the discrimination as justified (as the government had argued) because, firstly, nationals of other former SFRY Republics were assumed to have participated in aggression against Slovenia and secondly, their rights were the subject of succession negotiations and there was therefore no reason for Slovenia to assume responsibility pending the conclusion of a succession agreement. ${ }^{26}$

20. Ibid: [53].

21. See Gaygusuz v. Austria, 16 September 1996, § 42, Reports of Judgments and Decisions 1996 IV; and Andrejeva, cited above, $\S 87$.

22. See D.H. and Others v. the Czech Republic [GC], no. 57325/00, § 177, ECHR 2007 IV.

23. Ibid: [55]-[57].

24. Ibid: [58]-[59].

25. Ibid: [61].

26. Ibid: [62]-[67]. 


\section{Final remarks}

The judgment of the Court should be considered appropriate. Nationality cannot constitute a basis for discrimination with respect to access to social security benefits, unless it was objectively and reasonably justified. In the present case, no circumstances that justify derogation from the principle of non-discrimination pursuant to Art. 14 of the Convention exist. It seems that the Court could have included more detailed references to the arguments of the government in its judgment and explained why it does not consider these arguments as convincing circumstances that might justify different treatment of the applicant.

\section{Protection against the reimbursement of improperly collected social security benefits (Čakarević v. Croatia) ${ }^{27}$}

This review refers to the judgment of the European Court of Human Rights of 26 April 2018. The applicant, Ilinka Čakarević, stated in her complaint that the decision ordering her to return the improperly paid unemployment benefits constituted a violation of her property rights ${ }^{28}$ and of the right to respect the suspension of payment of her retirement pension during a period of employment in the public sector, as it constituted an unjustified interference with her property rights and an infringement on her right to respect her private life.

\section{Factual state}

On 10 December 1995, the applicant was dismissed from work due to her incapacity for work resulting from a prolonged illness. At that point in time, her period of employment as considered for the purposes of the calculation of employment benefit was 24 years and 10 months. ${ }^{29}$

On 5 November 1996, the Regional Office of the Croatian Employment Bureau in Rijeka (hereinafter: Rijeka Employment Bureau) granted the applicant unemployment benefit in Croation Kuna (equivalent to about EUR 55) for a period of 468 days. Later, in June $1997^{30}$ this benefit was extended for an indefinite period of time. Additionally, in December of that year the Employment Office added two years to the applicant's period of employment (which did not mean two years of performing work by the applicant, but only two years for the purposes of calculating the entitlement to social security benefits).

In March 2001, the Rijeka Employment Bureau deprived the applicant of the right to unemployment benefit, stating that the benefit had been granted in a manner not compliant with the law. Pursuant to legal regulations, persons with a period of employment shorter than 25 years (i.e. a group to which the applicant also belonged) were entitled to receive unemployment benefit for a period not exceeding 12 months. Only persons who had been employed for more than 25 years

27. Application no. $48921 / 13$ m 26.04.2018.

28. 'Every natural or legal person is entitled to the peaceful enjoyment of his possessions. No one shall be deprived of his possessions except in the public interest and subject to the conditions provided for by law and by the general principles of international law.

The preceding provisions shall not, however, in any way impair the right of a State to enforce such laws as it deems necessary to control the use of property in accordance with the general interest or to secure the payment of taxes or other contributions or penalties.'

29. Ibid: [6].

30. Ibid: [8]. 
were entitled to receive such benefits until the point at which they found a job. The Employment Office decided that the applicant had lost her right to sickness benefit on 9 July 1998. As a result, she was asked to return the amount of benefit paid after that date. The applicant appealed against the decision to the Administrative Court. The Court upheld the decision of the Office to revoke the benefit, but pointed out that the return of improperly paid benefits by the Office should be pursued in civil proceedings. ${ }^{31}$

As a result of the claim of the Rijeka Employment Bureau, in 2009, the Civil Court issued a judgment, ordering the Applicant to return the total amount of the benefits paid after 9 July 1998 with interest. $^{32}$

\section{The concept of possession in the jurisdiction of the European Court of Human Rights as a basis for the protection of social security benefits}

The applicant based her complaint on the violation of her property right, which is protected under Article1 of Protocol No. 1 to the Convention. The basis was, however, contested by the government. Evaluating the acceptability of the complaint, the Court analysed whether the unemployment benefit that had been paid, which the government demanded that the applicant return, was covered by the concept of possession developed on the basis of the aforementioned provision.

The Court pointed out that the concept of 'possessions' referred to in the first part of Article 1 of Protocol No. 1 has an autonomous meaning which is not limited to the ownership of physical goods and is independent of the formal classification in domestic law: certain other rights and interests constituting assets can also be regarded as 'property rights', and thus as 'possessions' for the purposes of this provision ${ }^{33}$ (see, among many authorities, Depalle v. France [GC], 2010). ${ }^{34}$ The Court also emphasised that, although Article 1 of Protocol No. 1 applies only to a person's existing possessions and does not create a right to acquire property, in certain circumstances a 'legitimate expectation' of obtaining an asset may also enjoy the protection of Article 1 of Protocol No. $1 .{ }^{35}$ At the same time, the Court made a reservation that the legitimate expectation must be of a nature more concrete than a mere hope and be based on a legal provision or a legal act such as a judicial decision. The mere fact that a property right is subject to revocation in certain circumstances does not prevent it from being a 'possession' within the meaning of Article 1 of Protocol No. 1, at least until it is revoked. ${ }^{36}$

The Court transposed the above considerations to the analysed case and emphasised that the key issue for assuming that Article 1 of Protocol No. 1 is applicable ratione materiae is to determine, whether in the circumstances of the case in question, the applicant can be said to have had a legitimate expectation, within the autonomous meaning of the Convention, of being able to retain

31. Ibid: [16]-[18].

32. This was a judgment of the Court of Appeal, which changed the judgment of the District Court that had held in favour of the Applicant. Although the Applicant appealed against the decision of the Court of Appeal to the Supreme Court and the Constitution Tribunal, her appeals were considered, respectively, as inadmissible and unfounded.

33. Ibid: [50], see also Iatridis v. Greece [GC], no. 31107/96, § 54, ECHR 1999-II.

34. Depalle v. France [GC], no. 34044/02, § 62, ECHR 2010.

35. Ibid: [51] see also Anheuser-Busch Inc. v. Portugal [GC], no. 73049/01, § 65, ECHR 2007-I; and Béláné Nagy v. Hungary [GC], no. 53080/13, § 74, ECHR 2016).

36. Ibid: [52] see Béláné Nagy, cited above, § 75; Beyeler v. Italy [GC], no. 33202/96, § 105, ECHR 2000 I; and Krstić v. Serbia, no. 45394/06, § 83, 10 December 2013). 
the funds already received as unemployment benefit without her entitlement to those past disbursements being called into question retrospectively. ${ }^{37}$

Assuming that such legitimate expectation existed, the Court provided five arguments supporting its position:

1) The applicant did not contribute to the error of the authorities that resulted in the payment of unemployment benefit for a period longer than that permitted by domestic law.

2) The good faith in which the applicant accepted her right to the benefit throughout the period when it was disbursed was never questioned.

3) The decision delivered to the applicant did not contain information that the benefit would be paid only for a period of 12 months.

4) There was a long lapse of time, amounting to over three years, after the expiry of the statutory time limit during which the authorities failed to react while continuing to make the monthly payments. ${ }^{38}$

5) The nature of the unemployment benefit and the situation of the applicant when she was receiving it justified her expectation that it was disbursed in compliance with the law. ${ }^{39}$

\section{The concept of peaceful enjoyment of property as a basis for protection against the obligation to return unduly paid benefits}

The Court assumed that the benefit awarded as unemployment benefit was subject to protection against the obligation to return the benefit paid, i.e. enjoyed the protection of Article 1 of Protocol No. 1. In consequence it was necessary to determine, whether the demand of authorities to return these benefits could be considered as acceptable. In order to do so, the Court analysed the factual state of the case in the light of three prerequisites: ${ }^{40}$ (i) whether that interference was prescribed by law, (ii) whether it pursued a legitimate aim, and (iii) whether there was a reasonable relationship of proportionality between the means employed and the aim pursued. ${ }^{41}$

Whether the interference was based in law. The Court pointed out that the legal basis for the actions of Romanian authorities was not completely clear. Although it was obvious that the Civil Court ordering the applicant to return improperly received benefits relied on section 210 of the Civil Obligations Act relating to unjust enrichment, ${ }^{42}$ it still did not give any explanation as to why section 55 of the Employment Mediation and Unemployment Rights Act was not to be applied in

37. Ibid: [54].

38. Ibid [59]-[62].

39. Ibid: [64].

40. Ibid: [72].

41. See Broniowski v. Poland [GC], no. 31443/96, §§ 147-151, ECHR 2004 V.

42. Section 210 of Civil Obligations Act (Zakon o obveznim odnosima, Official Gazette nos. 53/1991, 73/1991, 3/1994, 7/ 1996 and 112/1999): '(1) When a part of the property of one person passes, by any means, into the property of another person, and such a transfer has no basis in a legal transaction or law, the acquirer shall return that property. If this is not possible, the acquirer shall provide compensation for the value of the benefit received. (2) The transfer of property also includes any benefit obtained by someone performing an action. (3) The obligation to return the property or provide compensation for its value shall arise even when something is received on account of a cause which did not exist or which subsequently ceased to exist.' 
the applicant's case since that rule appears to be a more specific one as regards the applicant's situation. That provision obliged an unemployed person granted an allowance to which he or she had not been entitled to pay this back if it had been granted on the basis of false or inaccurate data which he or she had known to be false or inaccurate, or if it had been granted in some other unlawful manner. ${ }^{43}$ However, the Court decided not to rely on this basis in its judgment, stating that the issue of assessing the proportionality of the interference was more important for the ultimate result of the case. ${ }^{44}$

Whether the interference pursued a legitimate aim. The Court decided that the demand to return unduly received benefits had a legitimate aim. It pointed out that such action is justified by the protection of public interest by means of correcting an erroneous decision of the authorities. ${ }^{45}$

Whether the interference was proportionate. The Court stated that in order to determine whether the principle of proportionality had been complied with, it was, first of all, necessary to assess whether the balance between protecting the public interest and the right of the applicant to protect her right to the peaceful enjoyment of her possessions was maintained. Secondly, it was necessary to determine whether the decision of authorities imposed a disproportionate and excessive burden on the applicant. ${ }^{46}$

First of all, the Court emphasised that national authorities are fully entitled to correct a decision that mistakenly granted a specific allowance to a citizen. This is justified, among others, by the principle of legality. However, as mentioned in the jurisdiction of the ECHR multiple times, ${ }^{47}$ correcting erroneous decisions should in principle not be remedied at the expense of the individual concerned, especially where no other conflicting private interest is at stake. ${ }^{48}$

The Court emphasised that one should consider the fact that: ${ }^{49}$

a) Where an issue in the general interest is at stake, it is incumbent on the public authorities to act in good time, in an appropriate and consistent manner. ${ }^{50}$

43. Section 55 of the Employment Mediation and Unemployment Rights Act (Zakon o posredovanju pri zaposljavanju $i$ pravima za vrijeme nezaposlenosti, Official Gazette no. 32/2002): '(1) An unemployed person granted an allowance to which he or she was not entitled ... shall pay this back if: 1) [all or part of the allowance was] granted on the basis of false or inaccurate data which he or she knew or ought to have known to be false or inaccurate, or [granted] in some other unlawful manner; 2) He or she was granted an allowance because he or she failed to report a change affecting [his or her entitlement] or the scope of the entitlement, and he or she knew or ought to have known about this change....'

44. Ibid: [75].

45. Ibid: [76]: '(1) An unemployed person granted an allowance to which he or she was not entitled ... shall pay this back if: 1) [all or part of the allowance was] granted on the basis of false or inaccurate data which he or she knew or ought to have known to be false or inaccurate, or [granted] in some other unlawful manner; 2) He or she was granted an allowance because he or she failed to report a change affecting [his or her entitlement] or the scope of the entitlement, and he or she knew or ought to have known about this change....'

46. Ibid: [77].

47. See, mutatis mutandis, Platakou v. Greece, no. 38460/97, § 39, ECHR 2001 I; Radchikov v. Russia, no. 65582/01, § 50, 24 May 2007; Freitag v. Germany, no. 71440/01, §§ 37-42, 19 July 2007; Gashi, cited above, § 40; and Simecki v. Croatia, no. 15253/10, § 46, 30 April 2014.

48. Ibid: [80].

49. Ibid: [79]-[81].

50. See Tunnel Report Limited v. France, no. 27940/07, § 39, 18 November 2010; and Zolotas v. Greece (no. 2), no. 66610/ 09, § 42, ECHR 2013. 
b) The Convention is intended to safeguard rights that are 'practical and effective'.51

c) It must look behind appearances and investigate the realities of the situation complained. ${ }^{52}$

d) Uncertainty - be it legislative, administrative or arising from practices applied by the authorities - is a factor to be taken into account in assessing the State's conduct.

The Court decided that ordering the applicant to return the total overpaid amount was an excessive individual burden for her. ${ }^{53}$ This determination was based, first of all, on the behaviour of the authorities and of the applicant herself. The Court stated that, although section 25 of the Employment Act clearly provides that someone employed for less than 25 years has the right to unemployment benefit in respect of a temporary incapacity to work, for a maximum period of 12 months, the decision issued to the applicant did not contain any express mention of that time-limit, and the applicant was thus not put on notice of it. Moreover, given that two additional years of service had been added to the applicant's employment record it appears that she, as an unqualified worker, was not without grounds for believing that she met the requirements that entitled her to receive the benefit for a period exceeding 12 months. ${ }^{54}$ The Court also stated that, considering the fact that the benefit had been paid for nearly three years after the expiry of the statutory period in which the applicant was legally entitled to receive it, it should be considered that the authorities failed in their duty to act in good time and in an appropriate and consistent manner. ${ }^{55}$

The Court did not find any fault on part of the actions of the applicant. Moreover, it pointed out that, even though the unemployment benefit payments which the applicant should not have received were entirely the result of an error of the State, the applicant was ordered to repay the overpaid amount in full, together with statutory interest. Therefore, no responsibility of the State for creating the situation at issue was established, and the State avoided any consequences of its own error. The whole burden was placed on the applicant alone.

\section{Judgment}

As a result of the above considerations, the Court concluded that the actions of the authorities were not of a proportional nature, and thus that there had been a violation of Article 1 of Protocol No. 1 to the Convention. The Court did not assess the charge of violation of Art. 8 (having considered that it is, to a significant extent, similar to the charge raised in the light of Protocol No. 1 to the Convention).

\section{Final remarks}

The judgment of the Court should be considered appropriate. The Court stated very precisely why, in the case in question, the State could not demand the return of improperly paid social security benefits (unemployment benefits in this case). Not only does the judgment extend the concept of peaceful enjoyment of property developed by the Court in the light of Article 1 of Protocol No. 1 to

51. See also Chassagnou and Others v. France [GC], nos. 25088/94, 28331/95 and 28443/95, § 100, ECHR 1999-III.

52. See Broniowski, cited above, § 151; Hutten-Czapska v. Poland [GC], no. 35014/97, § 168, ECHR 2006 VIII; and Zammit and Attard Cassar v. Malta, no. 1046/12, § 57, 30 July 2015.

53. Ibid: [90].

54. Ibid: [83].

55. Ibid: [84]. 
the Convention, but it also constitutes an important element of strengthening the protection against charging citizens with the burden of errors made by administrative authorities.

\section{Declaration of conflicting interests}

The author(s) declared no potential conflicts of interest with respect to the research, authorship, and/or publication of this article.

\section{Funding}

The author(s) received no financial support for the research, authorship, and/or publication of this article. 